Article

\title{
Evaluation of the Bioavailability and Translocation of Selected Heavy Metals by Brassica juncea and Spinacea oleracea L for a South African Power Utility Coal Fly Ash
}

\author{
Aluwani Shiridor Mashau ${ }^{1}\left(\mathbb{B}\right.$, Mugera Wilson Gitari ${ }^{1, *} * \mathbb{C}$ and Segun Ajayi Akinyemi ${ }^{2}$ (i) \\ 1 Environmental Remediation and Nanoscience Group, Department of Ecology and Resources Management, \\ University of Venda, Private Bag X5050, Thohoyandou 0950, South Africa; shirldor.mashau03@gmail.com \\ 2 Environmental Remediation and Geopollution Group, Department of Geology, Faculty of Science, \\ Ekiti State University, Ado Ekiti, Private Mail Bag 5363, Ado Ekiti 360001 Nigeria; \\ segun.akinyemi@eksu.edu.ng \\ * Correspondence: mugera.gitari@univen.ac.za; Tel.: +27-15-962-8572
}

Received: 7 November 2018; Accepted: 8 December 2018; Published: 13 December 2018

\begin{abstract}
This study evaluated the physicochemical and mineralogical properties, mobile chemical species bioavailability and translocation in Brassica juncea and Spinacea oleracea L. plants of a South African coal-fired power utility. Coal-fly-ash (CFA) disposal is associated with various environmental and health risks, including air, soil, surface, and groundwater pollution due to the leaching of toxic heavy metals; these ends up in food webs affecting human health, while repeated inhalation causes bronchitis, silicosis, hair loss, and lung cancer. The morphology and chemical and mineralogical composition of CFA were determined using Scanning Electron Microscopy (SEM), $\mathrm{X}$-ray fluorescence (XRF), and X-ray diffraction, respectively. In pot-culture experiments, $S$. oleracea L. and B. juncea plants were grown in three sets of pots containing CFA (Set 1), soil (Set 2), and a mixture of CFA plus soil at a ratio of 1:1 (50\% CFA: $50 \%$ soil, Set 3), while no plants were grown in Set 4 as a control for the leachate samples. SEM showed that the surface morphology of CFA has a lower degree of sphericity with the irregular agglomerations of many particles. XRF results revealed that CFA contains $43.65 \%, 22.68 \%$, and $10.89 \%$ of $\mathrm{SiO}_{2}, \mathrm{Al}_{2} \mathrm{O}_{3}$, and $\mathrm{Fe}_{2} \mathrm{O}_{3}$, respectively, which indicates that CFA is an aluminosilicate material. X-ray diffraction (XRD) showed that CFA contains mullite as a major phase, followed by quartz mineral phases. Chemical species such as $\mathrm{B}, \mathrm{Ba}, \mathrm{Mo}$, and $\mathrm{Cr}$ were occurring at higher concentrations in the leachates for most weeks in the pot-culture experiments, especially for CFA and soil + CFA growth media. However, there was a common trend for all growth media of chemical-species concentrations declining with time, which might have been caused by plant uptake or wash-off with water during irrigation; even for the growth media as well, where no plants were grown. Chemical species, such as $\mathrm{Fe}, \mathrm{Mn}, \mathrm{B}, \mathrm{Ba}$, and $\mathrm{Zn}$, accumulated highly in most parts of the plant species. However, $B$. juncea showed higher potential to accumulate chemical species as compared to S. oleracea L. Bioconcentration and translocation factors (BF and TF) showed that $B$. juncea was the most effective in terms of bioconcentration and translocation of most of the chemical species. This indicates that $B$. juncea has potential in application for the phytoremediation of CFA dumps, and could contribute to the remediation of CFA dumps and the reduction of potential health and environmental impact associated with CFA.
\end{abstract}

Keywords: coal fly ash; leachates; chemical species; pot-culture experiments; translocation; bioconcentration 


\section{Introduction}

Coal-fly-ash dumps are a major source of chemical-species contamination of the environment as a whole. Maiti and Prasad [1] mentioned that coal-based thermal power plants generate coal fly ash (CFA) as the main industrial-waste product, at approximately 70\%-75\% [2], and it has been recognized as an environmental hazard across the globe. In South Africa, coal-fired power stations consume \pm 120 million tons of coal per annum, producing 30 million tons of CFA, to supply the bulk of South Africa's electricity. A modern coal-fired power station, with a total output of $3600 \mathrm{MW}$, was said to consume $\pm 50,000$ tons of coal every day by Eskom [3]. Eskom [3] mentioned that, depending on coal quality, heat, and ash content, stations can produce $\pm 17,000$ tons of ash per day. On the other hand, Sasol was producing about 7 million tons of ash, as reported by Reference [4]. Many of South Africa's thermal power plants use a wet-ashing process, while others use dry-ashing processes to dispose of ash. Usually, CFA is transported from the power plant, either damp or as a slurry, to a series of holding ponds where solids are allowed to settle out of suspension. CFA is usually then stockpiled and used as landfill. In dry-ashing systems, CFA is transported from the boilers by overland conveyors to ash-disposal facilities, and, since ash contains 12\% moisture, dust production is minimal [5].

Even though that is the case, agricultural lands have been continuously contaminated by direct discharge of industrial effluents, runoff wastewater from ash dumps, overflow of ash dykes during rainy seasons, or through the atmospheric fallout of CFA [6]. If soil and water get contaminated with industrial effluents containing high levels of chemical species, the chemical species find their way into food crops and vegetables and, consequently, enter the food web. Most of these chemical species are toxic and persistent at high concentrations, while some are toxic even at trace concentrations. They are regarded as environmental pollutants and pose a threat to the environment and human health [1]. Thus, improper CFA dumping will continue to cause land degradation, water, air, and soil pollution if preventive measures are not implemented. Dust emission of CFA causes air pollution and remains airborne for a long period, causing health hazards for the local masses. Henceforth, repeated inhalation of CFA dust containing crystalline silica can cause bronchitis, silicosis (scarring of the lung), lung cancer, and severe inflammation of the small airways of the lung, causing asthmalike symptoms. Exposure to some of the most common toxic contaminants in CFA, like Ni, causes allergic dermatitis known as nickel itch; inhalation can cause cancer of the lungs, nose, and sinuses; cancers of the throat and stomach have also been attributed to its inhalation; it is hematotoxic, immunotoxic, neurotoxic, genotoxic, reproductive-toxic, pulmonary-toxic, nephrotoxic, and hepatotoxic; it also causes hair loss [7].

Phytoremediation is a way to go about this pollution of air, soil, and water sources caused by CFA, where chemical species also end up in the food chain, affecting human life; it is a cost-efficient and ecologically benign process. This is because conventional remediation methods, such as acid leaching, land-filling, and excavation processes, are very expensive and not ecofriendly [8]. Phytoremediation is aimed at providing an innovative, economical, environmentally friendly approach for removing toxic chemical species from hazardous-waste sites [6]. It involves techniques such as rhizofiltration, phytostabilization, phytovolatilization, and phytoextraction. Emphasis is on phytoextraction because it involves chemical-species translocation to shoots, which is an important biochemical process and advantageous in effective phytoremediation. In other techniques, the harvest of root biomass is generally not feasible in many instances [7,9,10]. Goswami and Das [11] studied phytoremediation of cadmium-contaminated soil using B. juncea, and bioaccumulation was observed to be effective in the decontamination of the soil. Other plant species, like Ipomea carnea [12], Jatropha curcas [13], and Azolla caroliniana [14], are some that have been evaluated for the phytoremediation of CFA dumps. $B$. juncea and S. oleracea L. were chosen for the current study because they have certain characteristics that make them suitable for phytoremediation applications. This includes having a high growth rate, producing more aboveground biomass, accumulating more of the target chemical species from the soil, translocating accumulated chemical species from roots to shoots, tolerating the toxic effects of the 
target chemical species, adaptating well to prevailing environmental and climatic conditions, and being easy to cultivate and harvest [7,15-17].

The aim of this study was to determine the potential of S. oleracea L. and B. juncea in the phytoremediation of chemical species from CFA dumps. Therefore, the specific objectives were: (i) to evaluate the physicochemical and morphological composition of CFA from a selected South African coal-fired power utility, and (ii) to assess the bioavailability and translocation factor of chemical species in S. oleracea L. and B. juncea over a specific period of time and their potential for field application in the phytoremediation of such CFA dumps. There is a gap in the field of phytoremediation of CFA dumps, and most studies have focused more on the phytostabilization than the phytoextraction of CFA dumps, hence showing the significance of the current study.

\section{Materials and Methods}

\subsection{Materials}

The dry CFA used was collected from a selected South African coal-fired power utility. Good and viable seeds of Spinacia oleracea L. and Brassica juncea were purchased from a local store, sown in seed trays, and, thereafter, transplanted to pots for the growth experiments.

\subsection{Physicochemical Characterization of Coal Fly Ash}

The chemical and mineralogical composition of the CFA and soil were determined using X-ray fluorescence (XRF, ThermosFisher ARL Perform'X Sequential XRF instrument, Switzerland) and X-ray diffraction (XRD, Bruker, Germany), respectively. XRD analysis was done using a PANalytical X'Pert Pro powder diffractometer in $\theta-\theta$ configuration with an $X^{\prime}$ Celerator detector, variable divergence, and fixed receiving slits with Fe-filtered Co-K $\alpha$ radiation $(\lambda=1.789 \AA)$. Scanning Electron Microscopy (FEI Nova NanoSEM 230 with field emission gun, Eindhoven, Netherlands) was used to examine the morphology of CFA, and a Zeiss 1450 fully analytical scanning electron microscope was used.

\subsection{Experimental Design}

Pot-culture experiments were conducted for four successive months (April to July 2015). Prior to the experiment, the pots were thoroughly washed with Milli-Q water and filled up with different compositions of soil and CFA. Experiments were conducted in four sets. The first set was filled up with CFA, second set with soil only, the third set with a mixture of CFA and soil, and the last set was for control with only CFA. Spinacia oleracea L. and Brassica juncea plants were grown in three sets of pots, containing CFA (Set 1), soil (Set 2) and a mixture of CFA and soil at ratio 1:1 (50\% CFA: 50\% soil, Set 3). No plant was grown in Set 4 . Figure 1 shows the sets of used growth media. Seeds were sown in seed trays and irrigated daily until germination, then transplanted to pots. The pots were kept in a nursery to mimic the natural environment. The pots were monitored (measuring plant heights for growth performance) and leachates were collected daily; finally, the heights of the plants were recorded. Plants were irrigated daily and the collected leachate was analyzed using Inductively Coupled Plasma-Mass Spectrometry (Agilent 7900 ICP-MS, Agilent Technologies, Santa Clara, CA, US) for cationic chemical species. Harvesting of the plants was done in stages: the first harvest was of the seedlings (23 days), the second harvest was done after 69 days of growth, and the last harvest was done after 115 days of growth. This was chosen based on the stages of maturity of the two plant species; 23 days for the seedlings was when they were transplanted to bigger pots, 69 days as when the plants began to mature, and 115 days was when plants were fully matured. 
SET 1

(Pots filled with 100\% CFA for growing plants)

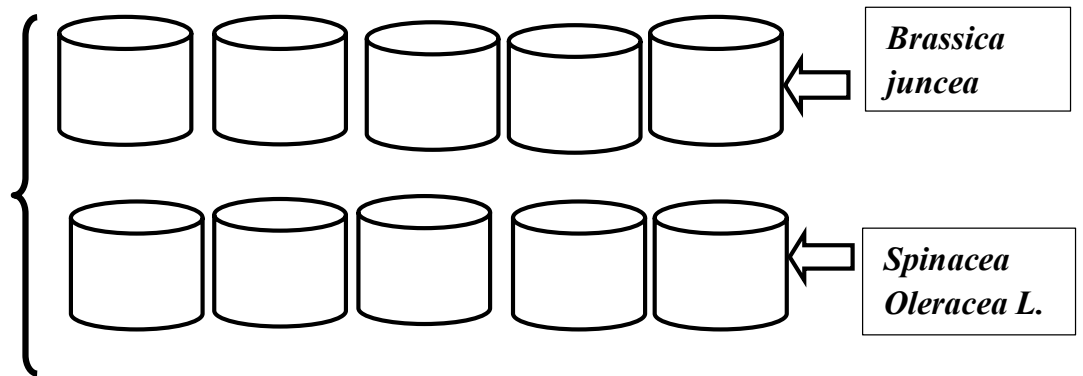

SET 2

(Pots filled with $100 \%$ soil for growing plants)

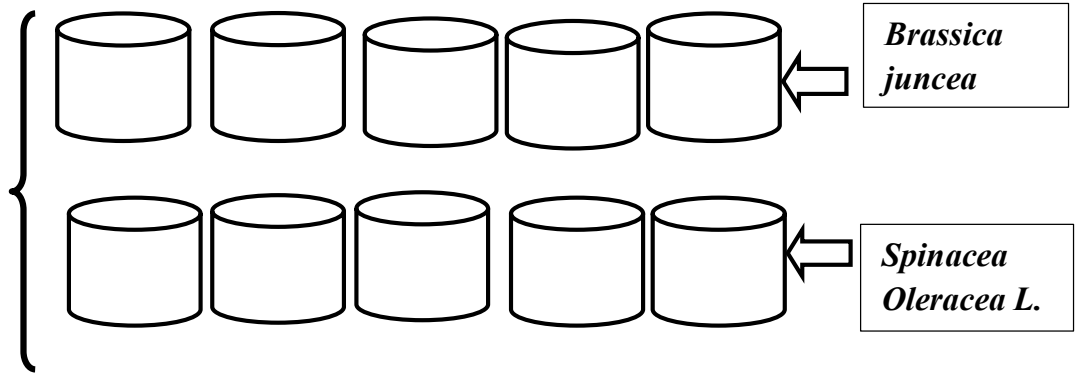

SET 3

(Amendment: $50 \%$ CFA and $50 \%$ soil)
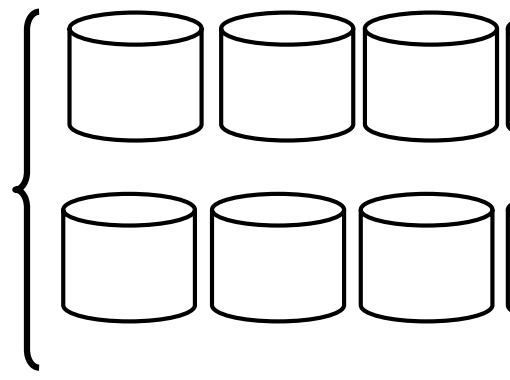

\section{SET 4}

(CFA only, no plants)

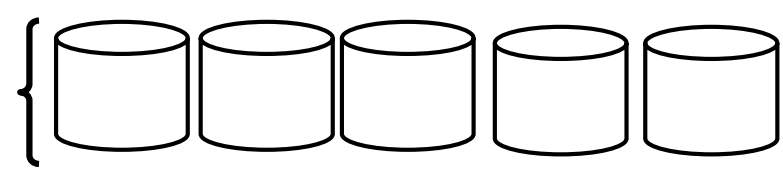

Figure 1. Illustration of pot setup (materials used in each pot and ratio used in case of combination is indicated; species grown in each pot is also shown). CFA: Coal-fly-ash.

\subsection{Preparation of Plant Samples for Bioaccumulation Analysis, Biomass Estimation, and Chlorophyll Content}

Samples of the whole plant were collected, then cut to separate parts, leaves, stems, and roots, in order to determine chemical-species concentrations in each part of the plant and for biomass estimation. The biomass of the plants was estimated by weighing the mass $(\mathrm{g})$ of plant sample after air-drying. To estimate chemical-species bioaccumulation, dried samples were ground into a fine powder, and $0.5 \mathrm{~g}$ was weighed for digestion through aqua regia $\left(\mathrm{HCl}: \mathrm{HNO}_{3}=3: 1(v / v)\right)$ to near dryness or until a white-colored solution was formed. Acid digestion was carried out on a hotplate. After complete digestion of the samples, $100 \mathrm{~mL}$ of MilliQ water $(18.2 \mathrm{M} \Omega / \mathrm{cm})$ was added and left to cool down. Samples were then filtered through a $0.45 \mu \mathrm{m}$ pore membrane. Samples were then analyzed using ICP-MS (Agilent 7900 ICP-MS, Agilent Technologies, Santa Clara, CA, US). Blanks and internal standards were set for quality assurance. Growth performance was obtained by measuring the heights of the plant species in the pot-culture experiments.

For chlorophyll analysis, the leaves of B. juncea and S. oleracea L. were accurately weighed, and $0.5 \mathrm{~g}$ of each fresh plant leaf sample was taken. This was sufficiently homogenized in a blender with $10 \mathrm{~mL}$ of the extracting solvent ( $90 \%$ ethanol). The homogenized sample mixture was centrifuged at 10,000 rpm for $15 \mathrm{~min}$ at $40{ }^{\circ} \mathrm{C}$. The supernatant was separated, and $0.5 \mathrm{~mL}$ of it was mixed with $4.5 \mathrm{~mL}$ of ethanol. The solution was transferred to a corresponding cell, put in a cell compartment, and analyzed for Chlorophyll-a, Chlorophyll-b, and carotenoid content using a spectrophotometer (SQ Pharo 100 
Spectroquant, Merk, Frankfurt, Germany). The chlorophyll contents were then determined using the following equations [18]:

$$
\begin{gathered}
\mathrm{Ch}-\mathrm{a}=13.36 \mathrm{~A}_{664}-5.19 \mathrm{~A}_{649} \\
\mathrm{Ch}-\mathrm{b}=27.43 \mathrm{~A}_{649}-8.12 \mathrm{~A}_{664} \\
\mathrm{Cx}+\mathrm{c}=\left(1000 \mathrm{~A}_{470}-2.13 \mathrm{Ch}-\mathrm{a}-97.63 \mathrm{Ch}-\mathrm{b}\right) / 209
\end{gathered}
$$

where $\mathrm{A}=$ Absorbance, $\mathrm{Ch}-\mathrm{a}=$ Chlorophyll $\mathrm{a}, \mathrm{Ch}-\mathrm{b}=$ Chlorophyll $\mathrm{b}$, and $\mathrm{C} \mathrm{x}+\mathrm{c}=$ Carotenoids .

\subsection{Bioconcentration Factor (BCF) and Translocation Factor (TF)}

$\mathrm{BCF}$ was calculated for each plant part (root, stem, leaf) using the following equations for the CFA and soil:

$$
\begin{aligned}
& \mathrm{BCFa}=\text { Metal in leaves/Metal in FA or soil. } \\
& \mathrm{BCFb}=\text { Metal in stem/Metal in FA or soil. } \\
& \mathrm{BCFC}=\text { Metal in roots/Metal in FA or soil. }
\end{aligned}
$$

where $\mathrm{BCFa}$ is the bioconcentration factor of the leaves, $\mathrm{BCFb}$ is the bioconcentration factor of the stem, and $\mathrm{BCFC}$ is the bioconcentration factor of the roots.

Then, TF, which is an asset to assess a plant's potential for phytoremediation purposes, was also calculated. TF is based on the ratio of metal concentration in a plant stem as compared to that of the plant root and leaves [19].

Thus:

$$
\begin{aligned}
\mathrm{TF} & =\mathrm{BCFa} / \mathrm{BCFb} \text { i.e., leaf } / \text { stem. } \\
\mathrm{TF} & =\mathrm{BCFb} / \mathrm{BCF} \text { i.e., stem } / \text { root }
\end{aligned}
$$

\subsection{Statistical Analysis and How Chemical-Species Concentrations Were Calculated in Plant Parts after Analysis}

Data were subjected to one-way analysis of variance (ANOVA) using a Graphpad software package (http://www.graphpad.com). The relationship between chemical elements in soil, FA, and FA + soil growth media, and also between the different plant parts (root, stem and leaf) of B. juncea and S. oleracea L., were calculated using the $t$-, ANOVA-Bartlett, and Mann-Whitney tests, and Kruskal-Wallis Statistics (KW) depending on each dataset. This was done to determine how well the datasets were related to each other with regards to the concentrations of chemical elements in each plant part and also in different growth media. Differences were considered significant at $p \leq 0.05$.

The dry-weight concentrations of the chemical elements in the plant parts were calculated using the following formula for both B. juncea and S. oleracea L.:

$$
P P M=\frac{C \times V}{W}
$$

where

$C=$ concentration value from ICP-MS;

$V=$ volume of the solution used in the analysis; and

$W=$ weight of the plant part used. 


\section{Results and Discussion}

\subsection{Physicochemical Characterization of a Selected South African Coal-Fired Power Utility}

Figure 2 depicts the morphology of CFA as determined by SEM at different magnification levels. It was observed that morphology of CFA had a lower degree of sphericity with irregular agglomerations of many particles, while there were dominant spherical particles and smaller sharp needlelike particles.

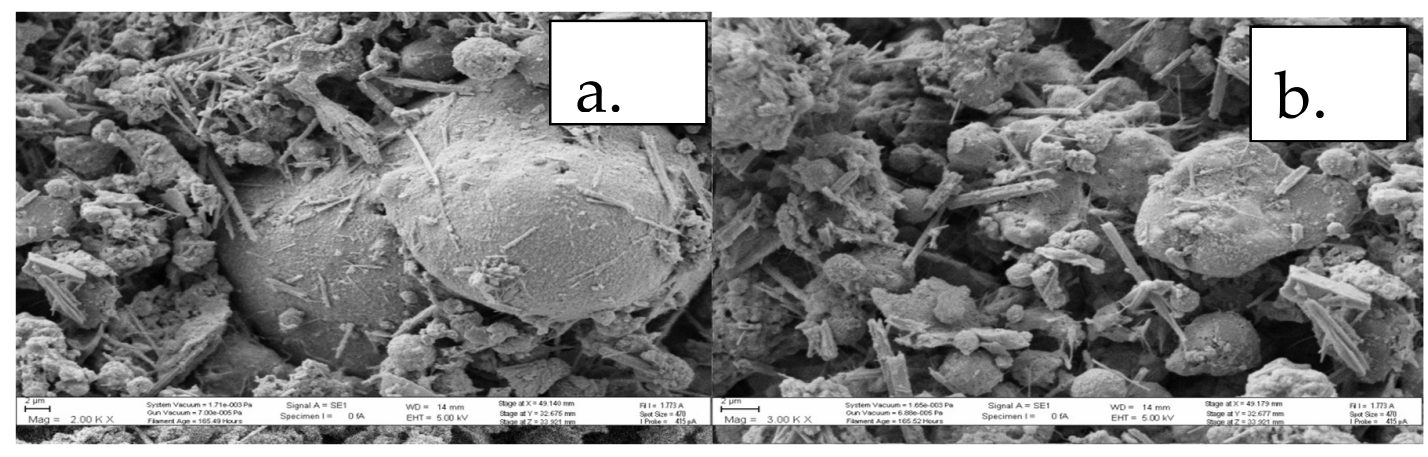

Figure 2. Scanning electron microscopy (SEM) micrographs of selected South African coal-fired power-utility coal fly ash (CFA) at (a) $\times 20,000$ and $(\mathbf{b}) \times 30,000$ magnifications.

Figure 3 presents the XRD spectrum of the CFA. The spectra showed the presence of mullite, quartz, calcite, hematite, magnetite, and albite as mineral phases in the CFA. Quantitative results from XRD showed that mullite was the dominant mineral (48.14\%), followed by quartz (28.51\%). Other mineral phases were at trace levels.

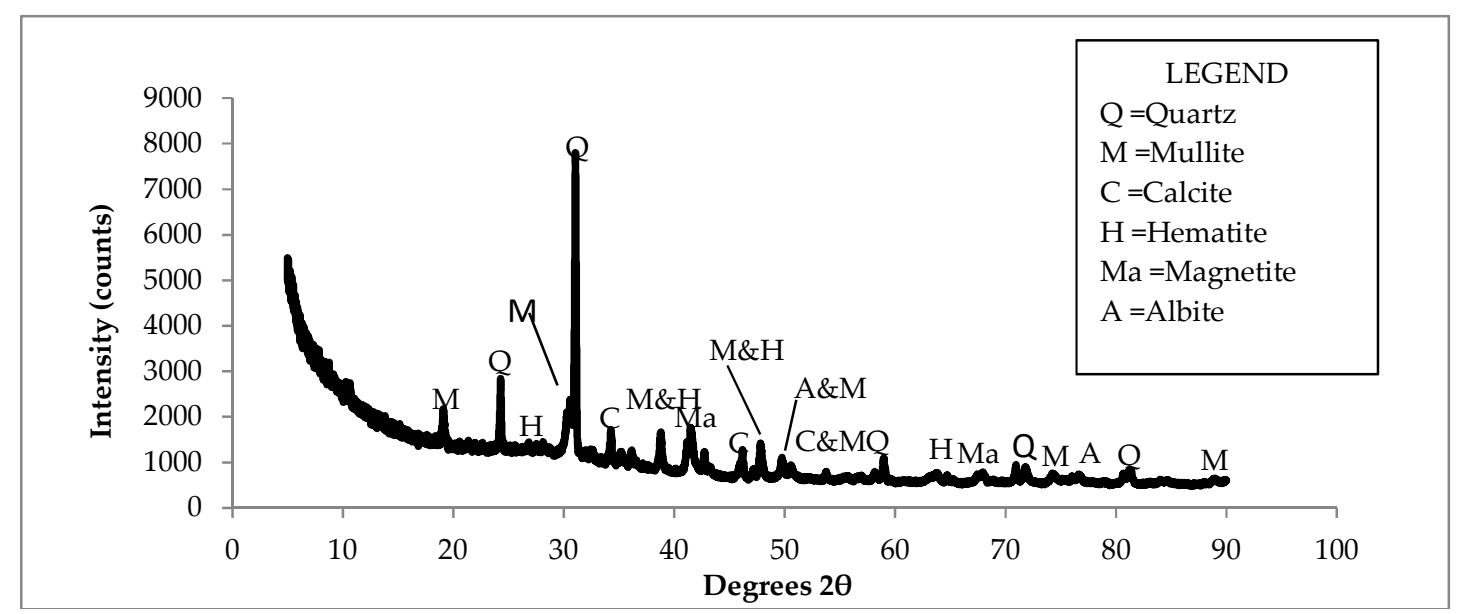

Figure 3. X-ray diffraction (XRD) spectrum of the CFA.

Table 1 shows the chemical composition of CFA and soil as determined by XRF. The analysis revealed that CFA consisted of $\mathrm{Fe}_{2} \mathrm{O}_{3}(10.89 \%), \mathrm{SiO}_{2}(43.65 \%)$, and $\mathrm{Al}_{2} \mathrm{O}_{3}(22.68 \%)$. The total percentage of these three oxides was $>70 \%$, indicating that this South African coal fly ash can be categorized as class $\mathrm{F}\left(\mathrm{SiO}_{2}\right.$-rich), which is derived either from anthracitic or bituminous coals [20]. The high concentration of $\mathrm{Fe}_{2} \mathrm{O}_{3}, \mathrm{SiO}_{2}$, and $\mathrm{Al}_{2} \mathrm{O}_{3}$ confirms that this CFA is an aluminosilicate material [21]. The soil had $\mathrm{SiO}_{2}(82.9 \%)$ as the main component, while $\mathrm{Fe}_{2} \mathrm{O}_{3}$ and $\mathrm{Al}_{2} \mathrm{O}_{3}$ were available in small amounts. Elements such as $\mathrm{Ni}, \mathrm{Cu}, \mathrm{Zn}, \mathrm{Zr}, \mathrm{W}, \mathrm{Sr}, \mathrm{Ni}, \mathrm{As}, \mathrm{Rb}$, and Mo were observed at trace levels in both CFA and soil. 
Table 1. Comparison of the chemical composition of CFA and soil samples.

\begin{tabular}{|c|c|c|c|c|c|c|c|}
\hline \multicolumn{4}{|c|}{ CFA Sample } & \multicolumn{4}{|c|}{ Soil Sample } \\
\hline $\begin{array}{l}\text { Major Elements } \\
\text { (as Oxides) }\end{array}$ & $(w / w) \%$ & $\begin{array}{c}\text { Trace } \\
\text { Elements }\end{array}$ & $\mathrm{mg} \mathrm{kg}^{-1}$ & $\begin{array}{l}\text { Major Elements } \\
\text { (as oxides) }\end{array}$ & $(w / w) \%$ & $\begin{array}{c}\text { Trace } \\
\text { Elements }\end{array}$ & $\mathrm{mg} \mathrm{kg}^{-1}$ \\
\hline $\mathrm{SiO}_{2}$ & 43.65 & As & 22 & $\mathrm{SiO}_{2}$ & 82.90 & As & 24 \\
\hline $\mathrm{TiO}_{2}$ & 1.23 & $\mathrm{Cu}$ & 57 & $\mathrm{TiO}_{2}$ & 0.54 & $\mathrm{Cu}$ & 17 \\
\hline $\mathrm{Al}_{2} \mathrm{O}_{3}$ & 22.68 & $\mathrm{Ga}$ & 35 & $\mathrm{Al}_{2} \mathrm{O}_{3}$ & 7.33 & $\mathrm{Ga}$ & 9 \\
\hline $\mathrm{Fe}_{2} \mathrm{O}_{3}$ & 10.89 & Mo & 9 & $\mathrm{Fe}_{2} \mathrm{O}_{3}$ & 3.31 & Mo & 8 \\
\hline $\mathrm{MnO}$ & 0.06 & $\mathrm{Nb}$ & 31 & $\mathrm{MnO}$ & 0.03 & $\mathrm{Nb}$ & 9 \\
\hline $\mathrm{MgO}$ & 1.88 & $\mathrm{Ni}$ & 63 & $\mathrm{MgO}$ & 0.25 & $\mathrm{Ni}$ & 20 \\
\hline $\mathrm{CaO}$ & 7.04 & $\mathrm{~Pb}$ & 29 & $\mathrm{CaO}$ & 0.36 & $\mathrm{~Pb}$ & 6 \\
\hline $\mathrm{Na}_{2} \mathrm{O}$ & 0.19 & $\mathrm{Rb}$ & 39 & $\mathrm{Na}_{2} \mathrm{O}$ & 0.71 & $\mathrm{Rb}$ & 51 \\
\hline $\mathrm{K}_{2} \mathrm{O}$ & 0.81 & $\mathrm{Sr}$ & 2001 & $\mathrm{~K}_{2} \mathrm{O}$ & 1.09 & $\mathrm{Sr}$ & 46 \\
\hline $\mathrm{P}_{2} \mathrm{O}_{5}$ & 0.54 & Th & 41 & $\mathrm{P}_{2} \mathrm{O}_{5}$ & 0.05 & Th & 13 \\
\hline $\mathrm{Cr}_{2} \mathrm{O}_{3}$ & 0.18 & $\mathrm{U}$ & 28 & $\mathrm{Cr}_{2} \mathrm{O}_{3}$ & 0.01 & $\mathrm{U}$ & 5 \\
\hline $\mathrm{NiO}$ & 0.01 & W & 48 & $\mathrm{NiO}$ & 0.00 & W & 235 \\
\hline $\mathrm{V}_{2} \mathrm{O}_{5}$ & 0.02 & $\mathrm{Y}$ & 65 & $\mathrm{~V}_{2} \mathrm{O}_{5}$ & 0.01 & $\mathrm{Y}$ & 10 \\
\hline $\mathrm{ZrO}_{2}$ & 0.07 & $\mathrm{Zn}$ & 40 & $\mathrm{ZrO}_{2}$ & 0.07 & $\mathrm{Zn}$ & 21 \\
\hline $\mathrm{CuO}$ & $<0.01$ & $\mathrm{Zr}$ & 507 & $\mathrm{CuO}$ & 0.00 & $\mathrm{Zr}$ & 405 \\
\hline $\mathrm{SO}_{3}$ & 0.36 & & & LOI & 3.02 & & \\
\hline LOI & 9.50 & & & TOTAL & 99.69 & & \\
\hline TOTAL & 99.11 & & & & & & \\
\hline
\end{tabular}

LOI: Loss On Ignition.

\subsection{Assessment of Biomass, Growth Performance, and Chlorophyll Content of Plant Species in} Pot-Culture Experiments

The biomass and growth performance of B. juncea and S. oleracea L. over time in different growth media are presented in Figures 4-7, respectively. Results showed that, in both growth media, the root, stem, and leaf biomass of B. juncea and S. oleracea L. plant species increased with increasing number of days. Based on the root and stem mass, $S$ oleracea $\mathrm{L}$. showed better tolerance in CFA as compared to $B$. juncea in CFA growth media. It is, therefore, anticipated that S. oleracea L. would yield better performance in phytoremediation because plants with extensive roots are capable of extracting more chemical species due to better exploration of growth media [13]. Furthermore, S. oleracea L. showed better growth in CFA media, while B. juncea grew better in the soil as a growth medium.

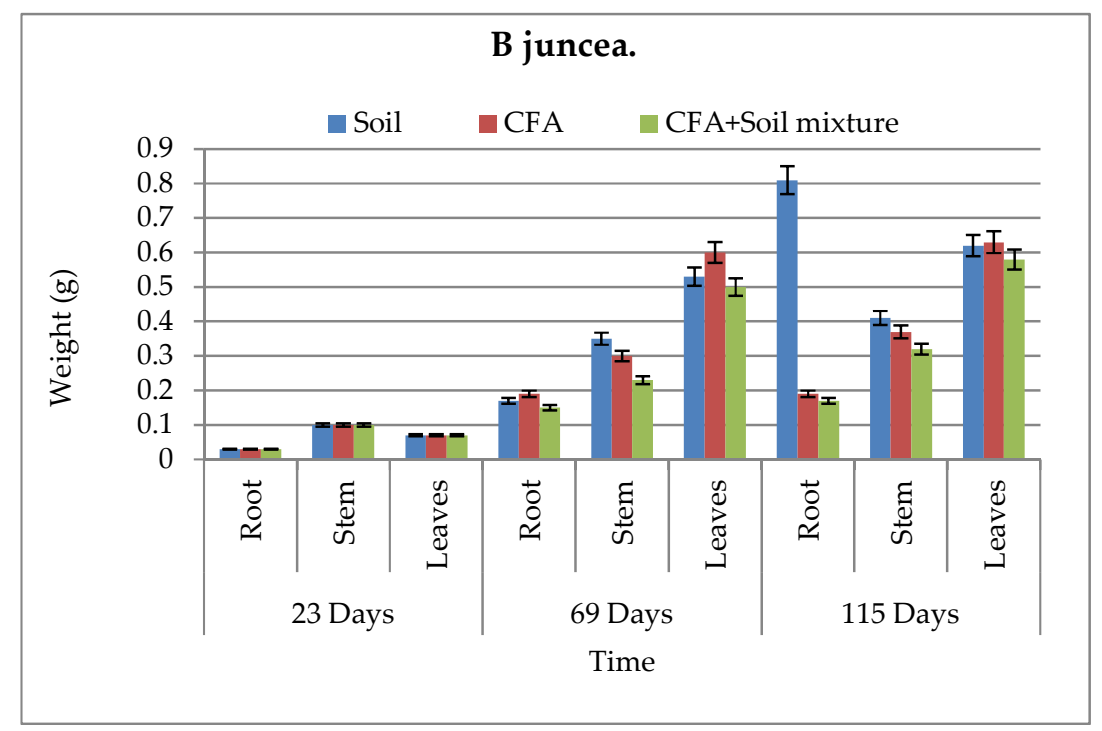

Figure 4. Above- and below-ground biomass for B. juncea in all growth media. CFA: Coal-fly-ash. 


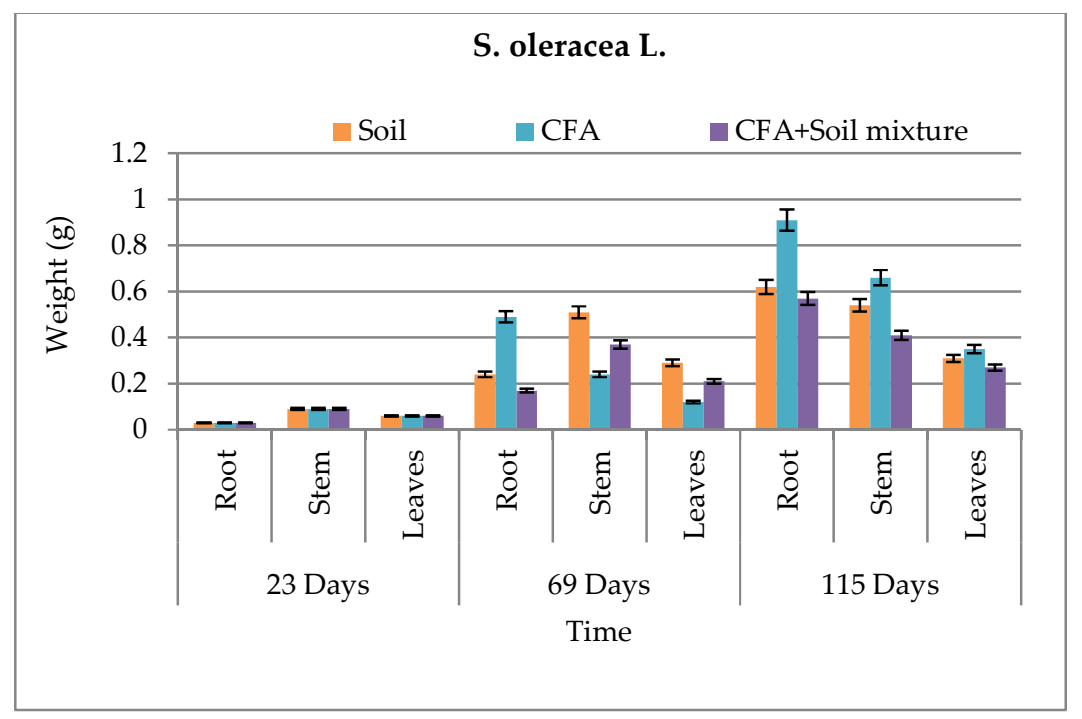

Figure 5. Above- and below-ground biomass for S. oleracea L. in all growth media. CFA: Coal-fly-ash.

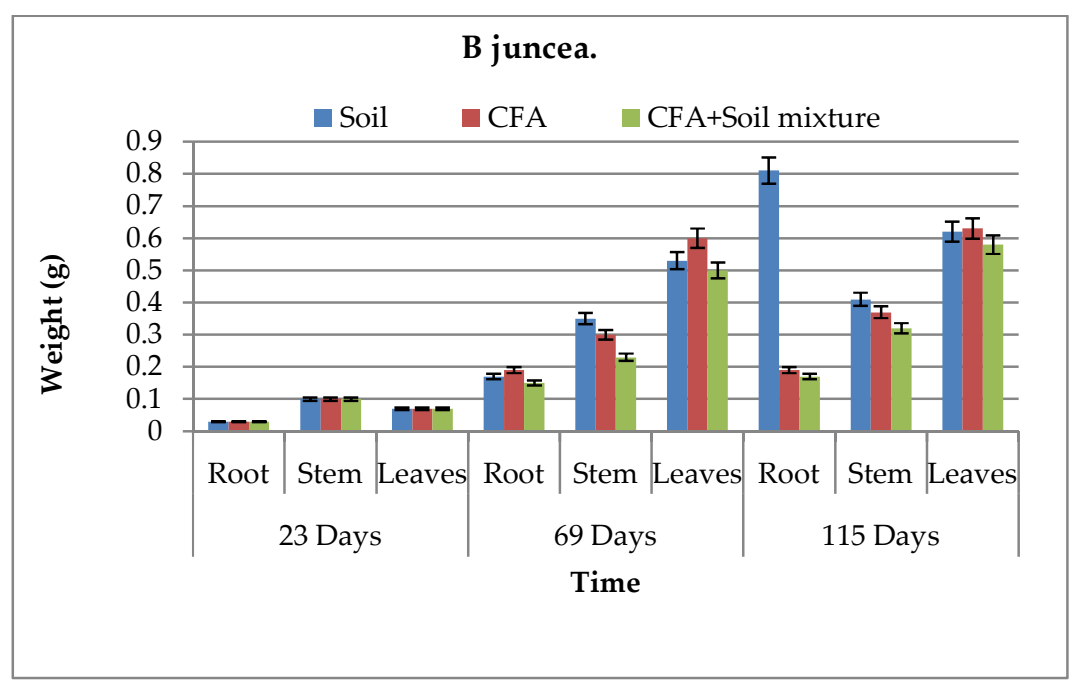

Figure 6. Growth performance of B. juncea in all growth media. CFA: Coal-fly-ash.

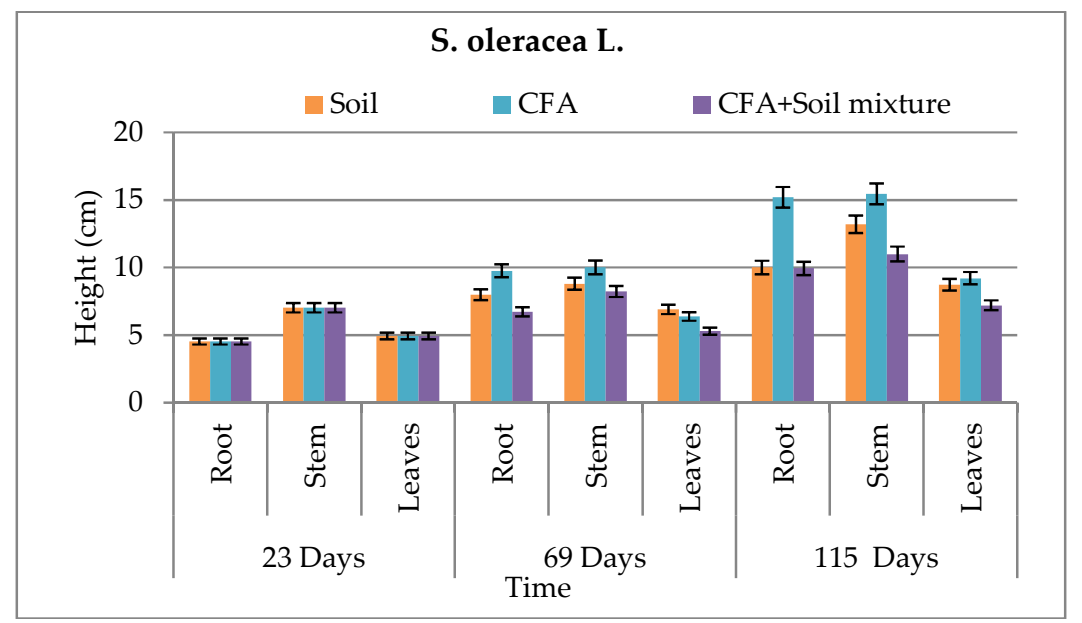

Figure 7. Growth performance of S. oleracea L. in all growth media. CFA: Coal-fly-ash.

It was observed that chlorophyll $\mathrm{a}$ and $\mathrm{b}$ increased during the first 69 days and declined in 115 days for some of the growth media (Table 2). This was observed in both plant species. Goswami 
and Das reported similar findings, where there was significant reduction in the total chlorophyll content of the young leaves of B. juncea and B. napus on exposure to $10 \mathrm{mM} \mathrm{Cd}$ for 15 days [11]. Compared to $B$. juncea, S. oleracea L. showed better chlorophyll b content. Even though that is the case, $B$ juncea showed to have more survival characteristics by having some carotenoid content while S. oleracea L.'s was not detected (Table 2). This carotenoid content in B. juncea plants can help in the protection of the plant species and improve its tolerance to harsh environments, including the high amounts of chemical species found in CFA; hence, it can promote its effectiveness in phytoremediation better than S. oleracea L. In an excess of light, carotenoids play an important role in photoprotection, and also have ecological significance [22]. Carotenoid content also protect plants against overexcitation in strong light, and dissipates excess absorbed energy; carotenoids scavenge reactive oxygen species formed during photo-oxidative stress and moderate the effect of extreme temperatures [23]. However, statistically, there was no significant difference between the two plant species in terms of growth performance and biomass, even between the plant parts denoting similar growth performance for the two plant species under study. This was because the $\mathrm{P}$ values for both species relative to the three different sets of growth media were greater than 0.05 , hence showing no significant difference. These statistical results confirm that the little difference we saw in Figures 4-7 was just not significant enough to have an effect on the biomass and growth performance of the plants under study. This might have been influenced by similar characteristics that the two plant species host, and the similar characteristics possessed by the soil and CFA used as the growth media for the pot-culture experiments.

Table 2. Chlorophyll a and b content of S. oleracea L. and B. juncea for different growth media with time.

\begin{tabular}{|c|c|c|c|c|c|c|}
\hline & \multicolumn{3}{|c|}{ Chlorophyll a for B. juncea } & \multicolumn{3}{|c|}{ Chlorophyll a for S. oleracea L. } \\
\hline & 23 days & 69 days & 115 days & 23 days & 69 days & 115 days \\
\hline Soil & 3.94 & 3.3 & 2.3 & 2.34 & 2.77 & 2.55 \\
\hline CFA & 3.94 & 2.63 & 2.25 & 2.34 & 2.65 & 1.44 \\
\hline \multirow[t]{2}{*}{ CFA + soil } & 3.94 & 4.11 & 3.94 & 2.34 & 2.64 & 2.75 \\
\hline & \multicolumn{3}{|c|}{ Chlorophyll b for B. juncea } & \multicolumn{3}{|c|}{ Chlorophyll b for S. oleracea $\mathrm{L}$. } \\
\hline Soil & 0.87 & 1 & 0.8 & 4.95 & 6.08 & 5.51 \\
\hline CFA & 0.87 & 1.57 & 1.79 & 4.95 & 5.62 & 3.12 \\
\hline \multirow[t]{2}{*}{ CFA + Soil } & 0.87 & 0.93 & 0.87 & 4.95 & 5.86 & 5.95 \\
\hline & \multicolumn{3}{|c|}{ Carotenoid content for $B$. juncea } & \multicolumn{3}{|c|}{ Carotenoid content for S. oleracea $\mathrm{L}$} \\
\hline Soil & 0.92 & 0.59 & 0.69 & ND & ND & ND \\
\hline CFA & 0.92 & 0.53 & 0.45 & ND & ND & ND \\
\hline CFA + Soil & 0.92 & 0.76 & 0.92 & ND & ND & ND \\
\hline
\end{tabular}

Note: $\mathrm{ND}=$ not detected; CFA: Coal-fly-ash.

\subsection{Temporal Evolution of the Physicochemical Characteristics of the Leachates as Plants Irrigated in Pot-Culture Experiment}

The temporal variation of the chemical elements in the leachates from different growth media is based on results for leachates collected from the first to the eleventh week of the pot-culture experiments for the different growth media. The full analysis results are presented in the supplementary information in Tables S1-S7. The selected chemical species presented include B, Cr, Mn, Ni, Cu, Zn, Mo, Ba, and Fe. They were chosen based on their higher concentrations in the leachates. Several authors have also indicated that these chemical species were present in CFA leachates in higher concentrations $[8,12,24]$.

In batch-leaching tests, soil leachates had a neutral $\mathrm{pH}$ of 7.22 with very high amounts of Si CFA leachates, meanwhile, had an alkaline $\mathrm{pH}$ of 10.62, which is known to be due to low sulfur content [14,25-27], and this can be seen in Table 1. In both soil and CFA, chemical species that were expected to be readily available to plants included $\mathrm{Ca}, \mathrm{Si}, \mathrm{K}, \mathrm{Ba}, \mathrm{Mo}, \mathrm{Na}, \mathrm{Al}, \mathrm{Mg}$, and $\mathrm{Sr}$, where $\mathrm{Si}, \mathrm{Ba}$, $\mathrm{Na}, \mathrm{Al}$, and $\mathrm{Sr}$ are nonessential elements as they were found in leachate solutions, which, if uptaken by plant roots, can have a negative impact on the plants. Physicochemical analysis of the soil, CFA, 
and CFA + soil leachates where plants were grown and where there were no plants showed that the alkalinity of the CFA changed over time (starting from an average of 9.4 to $7.5 \mathrm{pH}$ level in the 11th week) and there was also a decrease in the EC (starting from an average of 411 to $224 \mu \mathrm{S} \mathrm{cm}{ }^{-1}$ in the 11th week) due to the dissolution of soluble major oxides, which was promoted by continuous irrigation with water. Chemical species like B, Cr, Mo, and Ba (ranging from 4277.50 to $13.04 \mu \mathrm{g} \mathrm{L}^{-1}$ ) occurred at higher concentrations in leachates for most weeks for CFA and soil + CFA as a growth medium, while Fe (starting from 10,003.41 to $550.25 \mathrm{\mu g} \mathrm{L}^{-1}$ in the 11th week) was high for soil as a growth medium. It was observed that, in the 11th week of leachate collection, all these chemical species plummeted to very low concentrations. An example of the chemical elements that were found to be bioavailable in CFA leachate samples for S. oleracea L. can be seen in Figures 8-10. This suggests that these chemical elements could be reduced over time as plants are irrigated, which is either due to uptake by plants, or being washed off with water and/or CFA weathering processes [14]. A similar trend was observed for CFA, soil, and CFA + soil growth media. There was a significant difference in the concentrations of different chemical species in leachates from different growth media for each plant species (B. juncea and S. oleracea L.).

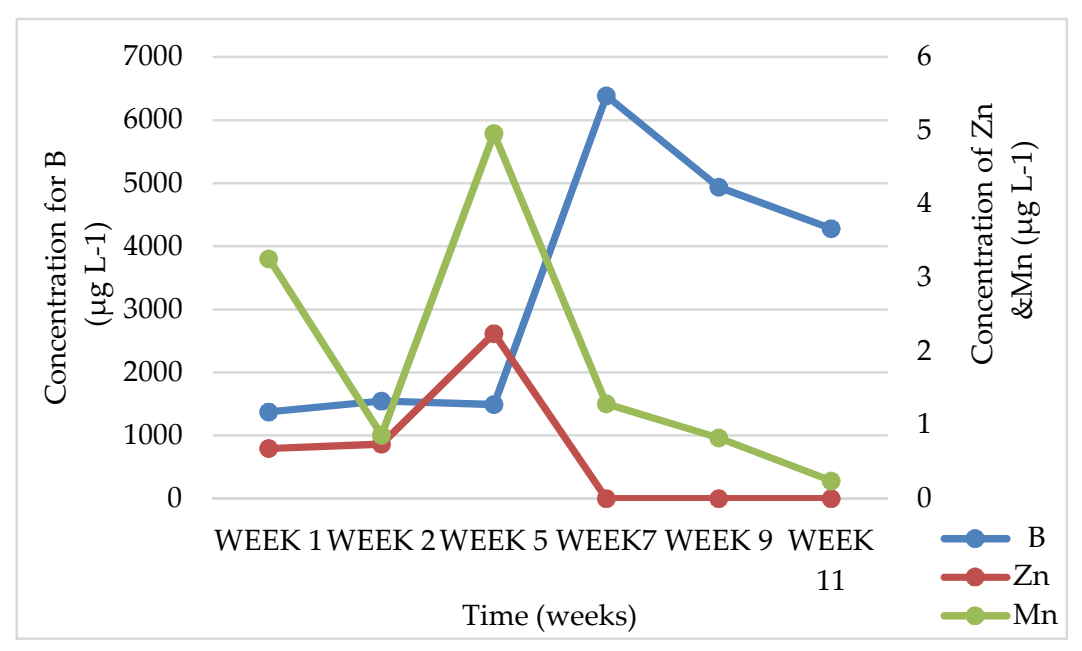

Figure 8. Chemical-element concentrations in leachates obtained from CFA (Coal-fly-ash) pots growing S. oleracea L. for essential elements B, Zn, and Mn.

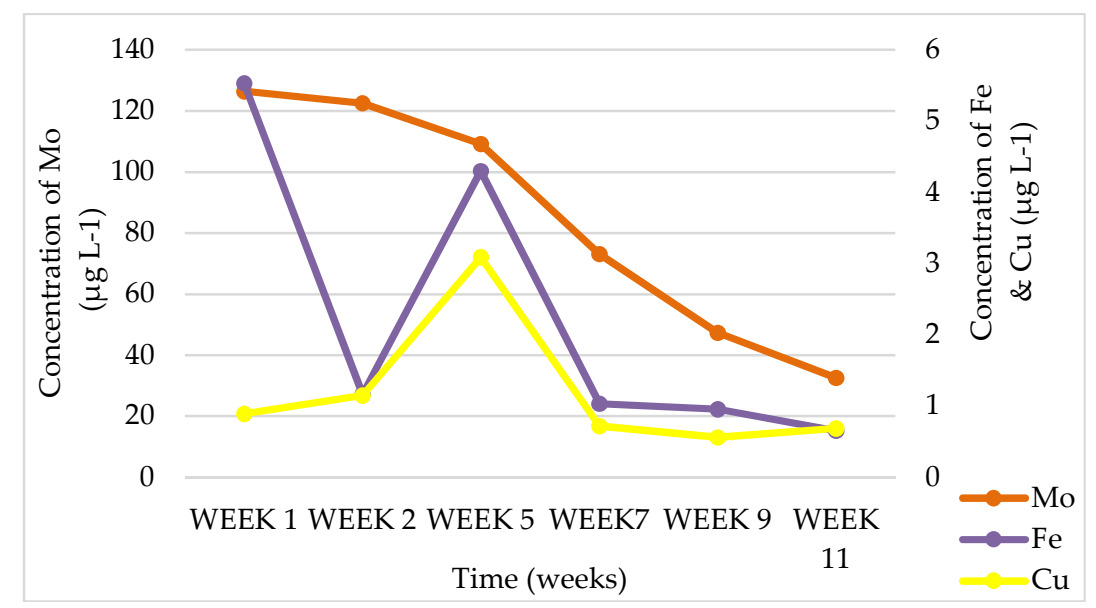

Figure 9. Chemical-element concentrations in leachates obtained from CFA (Coal-fly-ash) pots growing S. oleracea L. for essential elements $\mathrm{Fe}, \mathrm{Mo}$, and $\mathrm{Cu}$. 


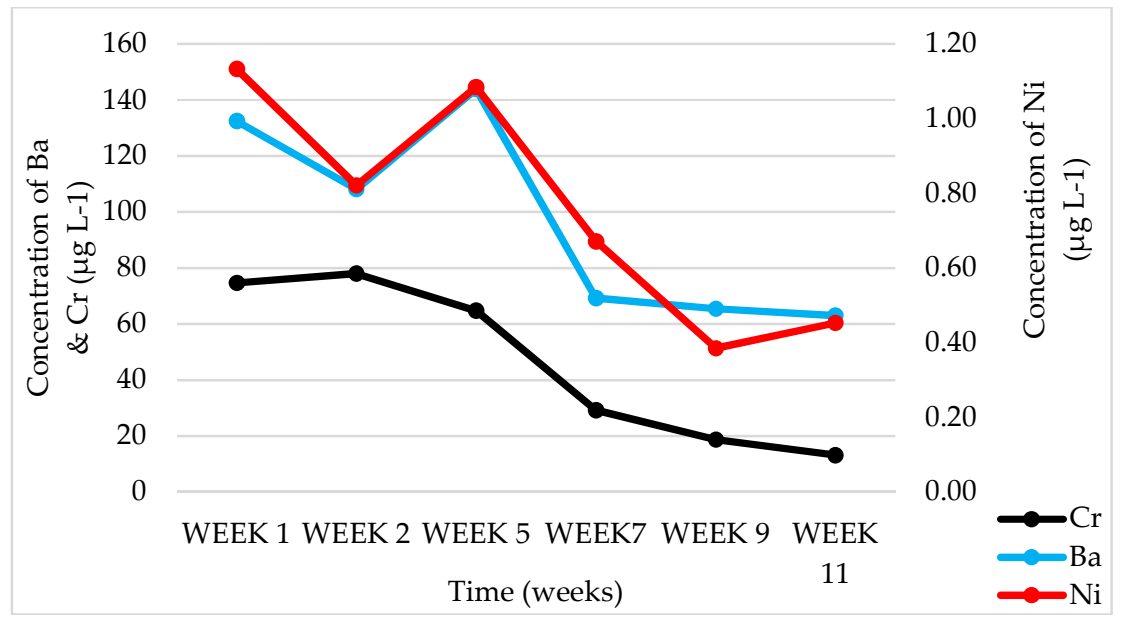

Figure 10. Chemical-element concentrations in leachates obtained from CFA (Coal-fly-ash) pots growing S. oleracea $\mathrm{L}$. for nonessential elements $\mathrm{Cr}$, Ni, and $\mathrm{Ba}$.

Figure 11 shows three out of the nine chemical elements that were found to be bioavailable in CFA where no plants were growing.

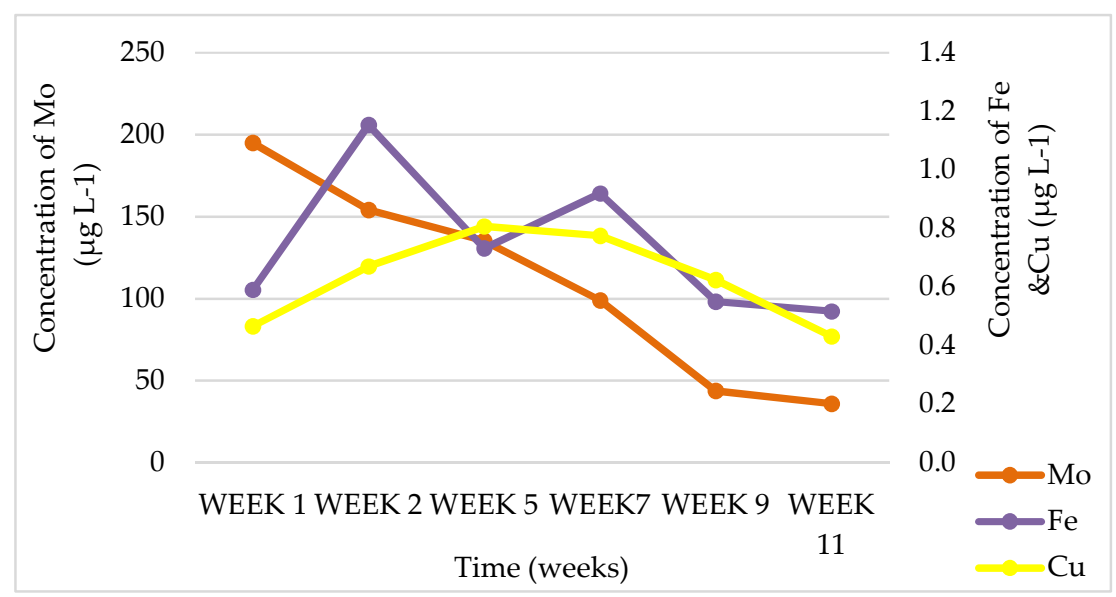

Figure 11. Chemical-element concentrations obtained from CFA (Coal-fly-ash) pots where no plants were grown for essential elements $\mathrm{Fe}, \mathrm{Mo}$, and $\mathrm{Cu}$.

Only this figure was presented because a similar trend can be observed for the other six chemical elements. Even here (just like in the pots were plant species were grown), the trend shows that chemical-element concentrations start high or increase during the earlier weeks, but at the final week (Week 11), we found them decreased in concentration. This marked similarity might be associated with the $\mathrm{pH}$ levels that also show some similarity in leachates for the different observed weeks. Pandey also mentioned that the chemical composition of CFA leachates is affected by the weathering of CFA over time, resulting in lower concentrations in the final week (Week 11) of the collected leachates for the current study [14].

\subsection{Potential of Plant Species for Phytoremediation}

The phytoremediation potential of a plant is assessed by computing the BCF and TF of the chemical species throughout the plant. A BCF value of more than 1 indicates that the plant is a potential accumulator of chemical species, while a TF value greater than 1 indicates that the plant is a potential translocator of chemical species. These also show the role and importance of plant species used for the current study on the uptake and translocation of chemical elements to shoots, allowing detoxification in the process without affecting the physiology of the plants. 
Table 3 shows the BCF for chemical species accumulating in B. juncea and S. oleracea L. on Day 115 for all growth media. Higher BCF values were observed for $\mathrm{Fe}, \mathrm{Mn}, \mathrm{Zn}, \mathrm{Cu}$, and $\mathrm{Ni}$ in the plant parts of both plants. Conversely, lower values were observed for $\mathrm{Mo}, \mathrm{B}, \mathrm{Ba}$, and $\mathrm{Cr}$, having $\mathrm{BCF}$ values less than 1 for most growth media over time. From the results, it was concluded that $B$ juncea is more suitable for the accumulation of many chemical species than S. oleracea L. in CFA and soil as a growth medium (Table 3). Chemical-species accumulation trends depend on factors such as the age and type of the plant, chemical-species concentrations in CFA, and also the season of sampling [14]; this is the reason why accumulation was different over time for the current study (See details on 69 days in Table S8 in the supplementary materials). For the CFA + soil-growth media, B juncea accumulated many different chemical species than S. oleracea L. in 115 days. This is the growth medium where S. oleracea $\mathrm{L}$. did better than other growth media in terms of the accumulation of different chemical species. Similar results were obtained by Pandey, but using a different plant species for the phytoremediation of CFA dumps. The results indicated the efficiency of Azolla caroliniana for the phytoremediation of the CFA pond because of its higher bioconcentration factor. The metal concentration ranged from 175 to 538 and 86 to $753 \mathrm{mg} \mathrm{kg}^{-1}$ in roots and fronds, respectively [14].

Table 3. Bioconcentration Factor (BCF) for chemical species accumulating in both plant species on Day 115 for all growth media.

\begin{tabular}{|c|c|c|c|c|c|c|c|c|c|}
\hline \multicolumn{10}{|c|}{ B. juncea } \\
\hline \multirow{2}{*}{ Growth Media } & \multicolumn{3}{|c|}{ Soil } & \multicolumn{3}{|c|}{ CFA } & \multicolumn{3}{|c|}{ CFA + Soil } \\
\hline & Leaf & Root & Stem & Leaf & Root & Stem & Leaf & Root & Stem \\
\hline B & 2.67 & 1.01 & 2.40 & 0.12 & 0.08 & 0.06 & 0.07 & 0.02 & 0.03 \\
\hline $\mathrm{Cr}$ & 5.66 & 4.37 & 2.06 & 1.00 & 1.08 & 0.55 & 2.13 & 0.58 & 0.65 \\
\hline $\mathrm{Mn}$ & 24.00 & 15.79 & 7.72 & 309.84 & 200.39 & 262.18 & 315.57 & 118.69 & 106.95 \\
\hline $\mathrm{Ni}$ & 1.20 & 1.32 & 0.59 & 24.57 & 24.32 & 11.75 & 10.66 & 3.47 & 3.28 \\
\hline $\mathrm{Cu}$ & 6.53 & 5.96 & 2.46 & 27.58 & 19.96 & 25.26 & 9.31 & 4.44 & 3.78 \\
\hline $\mathrm{Zn}$ & 16.43 & 28.56 & 11.90 & 185.73 & 181.15 & 196.67 & 85.29 & 44.32 & 35.85 \\
\hline Mo & 7.29 & 1.12 & 3.24 & 0.28 & 0.15 & 0.15 & 0.03 & 0.02 & 0.03 \\
\hline $\mathrm{Ba}$ & 2.72 & 2.36 & 1.86 & 1.22 & 1.10 & 1.38 & 1.32 & 0.50 & 0.52 \\
\hline $\mathrm{Fe}$ & 68.31 & 50.51 & 17.89 & 979.08 & 692.36 & 1098.15 & 4046.11 & 1128.22 & 1047.44 \\
\hline \multicolumn{10}{|c|}{ S. oleracea L. } \\
\hline \multirow{2}{*}{ Growth Media } & \multicolumn{3}{|c|}{ Soil } & \multicolumn{3}{|c|}{ CFA } & \multicolumn{3}{|c|}{ CFA + Soil } \\
\hline & Leaf & Root & Stem & Leaf & Root & Stem & Leaf & Root & Stem \\
\hline B & 0.11 & 0.11 & 0.11 & 0.01 & 0.01 & 0.01 & 0.01 & 0.01 & 0.01 \\
\hline $\mathrm{Cr}$ & 1.13 & 1.13 & 1.13 & 0.38 & 0.38 & 0.38 & 1.24 & 1.24 & 1.24 \\
\hline Mn & 6.92 & 6.89 & 6.90 & 97.36 & 97.28 & 97.32 & 8.01 & 8.00 & 8.00 \\
\hline $\mathrm{Ni}$ & 0.51 & 0.51 & 0.51 & 11.24 & 11.23 & 11.23 & 6.10 & 6.10 & 6.10 \\
\hline $\mathrm{Cu}$ & 1.94 & 1.93 & 1.93 & 17.62 & 17.61 & 17.61 & 9.36 & 9.36 & 9.36 \\
\hline $\mathrm{Zn}$ & 5.67 & 5.65 & 5.66 & 42.96 & 42.93 & 42.95 & 91.92 & 91.91 & 91.92 \\
\hline Mo & 0.24 & 0.24 & 0.24 & 0.01 & 0.01 & 0.01 & 0.01 & 0.01 & 0.01 \\
\hline $\mathrm{Ba}$ & 0.34 & 0.34 & 0.34 & 0.48 & 0.48 & 0.48 & 0.35 & 0.35 & 0.35 \\
\hline $\mathrm{Fe}$ & 0.22 & 0.22 & 0.22 & 957.95 & 957.33 & 957.31 & 257.23 & 257.19 & 257.20 \\
\hline
\end{tabular}

Table 4 shows the translocation factor of various chemical species over time (115 days) in different plant species grown in different growth media with respect to the translocation of chemical species from the roots to the shoots of the plant species under study. The B. juncea species was observed to be an effective translocator of various chemical species (including $\mathrm{Zn}$ ) for different growth media. In most cases, TF values $>1$ were observed for $B$. juncea, while $S$. oleracea L. failed to translocate most chemical species $(\mathrm{TF}<1)$. Translocation was significant from the stems to the leaves of $B$. juncea in soil-growth media, followed by CFA, and then lastly by CFA + soil-growth media. Hence, it could be a potential CFA-dump phytoremediator. There was also significant chlorophyll and carotenoid content in B. juncea, leading to better tolerance in CFA media, while S. oleracea L. did not possess any carotenoid 
content that might have weakened its chemical-species accumulation potential. Goswami and Das studied the cadmium phytoremediation potential of B. juncea, and calculated the enrichment coefficient and root to shoot translocation factor that pointed toward the suitability of $B$. juncea for removing $C d$ from soil [11]. Hence, B. juncea has the potential of accumulating many different pollutants, just like in the current study, where nine chemical elements were removed and translocated to the shoots. In the other study, it was suggested that Jatropha curcas has the potential to establish itself on CFA when provided with basic plant nutrients, and can manifold accumulating heavy metals from FA without attenuating plant growth [13].

Table 4. Translocation Factor (TF) of various chemical species for 115 days in different species of plants grown in different growth media. $\mathrm{TF}=\mathrm{BCFb} / \mathrm{BCF}$, i.e., stem $/$ root, and $\mathrm{TF}=\mathrm{BCFa} / \mathrm{BCFb}$, i.e., leaf/stem.

\begin{tabular}{|c|c|c|c|c|c|c|c|c|c|c|c|c|}
\hline & \multicolumn{6}{|c|}{ B. juncea } & \multicolumn{6}{|c|}{ S. oleracea L. } \\
\hline & \multicolumn{3}{|c|}{ Leaf/Stem } & \multicolumn{3}{|c|}{ Stem/Root } & \multicolumn{4}{|c|}{ Leaf/Stem } & \multicolumn{2}{|c|}{ Stem/Root } \\
\hline & Soil & CFA & CFA + Soil & Soil & CFA & CFA + Soil & Soil & CFA & CFA + Soil & Soil & CFA & CFA + Soil \\
\hline B & 3.57 & 5.15 & 1.79 & 2.37 & 0.74 & 1.33 & 1.06 & 0.68 & 2.75 & 1.21 & 1.85 & 0.77 \\
\hline $\mathrm{Cr}$ & 4.84 & 3.32 & 1.03 & 0.47 & 0.51 & 1.13 & 2.55 & 0.25 & 0.45 & 0.77 & 1.35 & 0.66 \\
\hline Mn & 3.86 & 4.44 & 1.08 & 0.49 & 1.32 & 0.91 & 0.63 & 18.75 & 3.70 & 0.45 & 0.05 & 0.59 \\
\hline $\mathrm{Ni}$ & 4.04 & 2.90 & 1.01 & 0.45 & 0.48 & 0.94 & 0.98 & 1.58 & 0.57 & 0.46 & 0.16 & 0.40 \\
\hline $\mathrm{Cu}$ & 4.35 & 3.34 & 1.20 & 0.41 & 1.27 & 0.85 & 1.17 & 1.75 & 0.62 & 0.61 & 0.24 & 0.42 \\
\hline $\mathrm{Zn}$ & 4.22 & 3.26 & 1.24 & 0.42 & 1.09 & 0.81 & 0.80 & 0.44 & 1.42 & 0.55 & 1.25 & 0.65 \\
\hline Mo & 8.95 & 5.46 & 3.36 & 2.88 & 0.97 & 1.72 & 1.72 & 1.30 & 3.59 & 0.76 & 1.12 & 0.66 \\
\hline Ba & 2.64 & 3.10 & 1.22 & 0.79 & 1.26 & 1.05 & 0.60 & 1.50 & 1.16 & 0.65 & 0.38 & 0.56 \\
\hline $\mathrm{Fe}$ & 5.38 & 3.68 & 0.91 & 0.35 & 1.59 & 0.93 & 2.39 & 2.80 & 0.59 & 0.60 & 0.17 & 0.61 \\
\hline
\end{tabular}

The differences in the metal concentrations of the plant parts (root, stem, leaf) suggest different cellular mechanisms of bioaccumulation that may manage and control their translocation and partitioning in plant systems $[12,28]$. Soluble chemical elements can enter roots either via cell-wall free space (apoplastic pathway) or by transport, across the plasma membrane of root cells and movement through the cytoplasm (symplastic pathway). They may also travel across the cell and ultimately enter the translocation stream [11].

\section{Conclusions}

The findings of the current study show that CFA is an aluminosilicate material with an alkaline $\mathrm{pH}$. CFA morphology showed that it has a lower degree of sphericity with irregular agglomerations of many particles, while there were dominant spherical particles and smaller, sharp, needlelike particles. There was similarity in terms of the elemental composition of CFA and soil used in this study since $\mathrm{SiO}_{2}$ was available in both media as a major oxide, which gives an expectation of similar growth of the plants in both media. Chemical species, such as $\mathrm{B}, \mathrm{Ba}, \mathrm{Mo}$, and $\mathrm{Cr}$, occurred at higher concentrations in the leachates for most weeks in the pot-culture experiments, especially for CFA and soil + CFA growth media. Fe also dominated, but only in soil as a growth medium. In terms of biomass estimation, growth performance, and the chlorophyll content of both plants, S. oleracea L. showed better growth in CFA media, while B. juncea grew better in the soil as a growth medium. It was observed that chlorophyll $\mathrm{a}$ and $\mathrm{b}$ increased during the first 69 days, and declined in 115 days for some growth media. Furthermore, there was some carotenoid content found in B. juncea, while none was detected for S. oleracea L. Because carotenoid content is important in the protection of plant, this could be attributed to the better adaptability of $B$. juncea for growth in CFA, and being a better bioaccumulator and translocator of chemical species. Hence, it could be more effective plant for phytoremediation than $S$ oleracea L. The superiority of $B$. juncea was confirmed with a BCF and TF $>1$ for most chemical species as compared to $S$. oleracea $L$. This study observed that $B$. juncea is a plant species that can potentially be applied on a field scale for the phytoremediation of CFA dumps. This could significantly lead to the reduction of the environmental and health impact of coal fly ash dumps, especially for communities 
leaving near such coal-fly-ash storage facilities. However, there is still a need for the assessment of other plant species.

Supplementary Materials: The following are available online at http://www.mdpi.com/1660-4601/15/ 12/2841/s1, Table S1: Chemical-element concentrations in leachates obtained from soil pots growing S. oleracea L., Table S2 Chemical-element concentrations in leachates obtained from CFA pots growing S. oleracea L., Table S3: Chemical-element concentrations in leachates obtained from CFA + soil pots growing S. oleracea L., Table S4: Chemical-element concentrations in leachates obtained from soil pots growing B. juncea., Table S5: Chemical-element concentrations in leachates obtained from CFA pots growing B. juncea., Table S6: Chemical-element concentrations in leachates obtained from CFA + soil pots growing $B$. juncea., Table S7: Chemical-element concentrations in leachates obtained from CFA pots where no plants were grown, Table S8: BCF for chemical elements accumulating in B. juncea and S. oleracea L. from 69 to 115 days for all growth media.

Author Contributions: M.W.G. developed the research concept, A.S.M. carried out the experiments and drafted the manuscript, M.W.G. edited the manuscript, S.A.A. helped with editing the manuscript, and M.W.G. was the supervisor of A.S.M.

Funding: This research received no external funding.

Acknowledgments: The authors would like to acknowledge the Sasol Inzalo Foundation, the National Research Foundation (NRF), the University of Venda Research Publication Committee (RPC) for their financial support, and the Environmental Remediation and Nanosciences Group DHET for their incentive funds.

Conflicts of Interest: The authors declare no conflict of interest.

\section{References}

1. Maiti, D.; Prasad, B. Revegetation of fly ash-A review with emphasis on grass-legume plantation and bioaccumulation of metals. Appl. Ecol. Environ. Res. 2016, 14, 185-212. [CrossRef]

2. Belyaeva, N.O.; Haynes, J.R. Comparison of the effects of conventional organic amendments and biochar on the chemical, physical and microbial properties of coal fly ash as a plant growth medium. Environ. Earth Sci. 2012, 66, 1987-1997. [CrossRef]

3. Eskom. Eskom and Ash Management. Eskom Holdings SOC Ltd, 2016. Available online: www.eskom.co. $\mathrm{za} /$ news/Pages/Feb20.aspx (accessed on 11 March 2018).

4. Matjie, R.H.; Ginster, M.; Van Alphen, C.; Sobiecki, A. Detailed Characterization of Sasol Ashes. Available online: http://www.flyash.info/2005/95mat.pdf (accessed on 5 May 2018).

5. Kalele, P.; Reddy, P.; Roods, M. Environmental Scoping Report for the Proposed Continuous Ash Disposal Facility for the Matimba Power Station in Lephalale, Limpopo Province. Available online: https://www.sahra.org.za/sahris/sites/default/files/additionaldocs/Matimba\%20Ash\%20Disposal\% 20Facility-\%20Draft\%20ESR-Final-Complete\%20Doc-red\%20size.pdf (accessed on 8 May 2015).

6. Kisku, G.C.; Kumar, V.; Sahua, P.; Kumar, P.; Kumar, N. Characterization of coal fly ash and use of plants growing in ash pond for phytoremediation of metals from contaminated agricultural land. Int. J. Phytorem. 2018, 20, 330-337. [CrossRef]

7. Ali, H.; Khan, E.; Sajad, M.A. Phytoremediation of heavy metals-Concepts and applications. Chemosphere 2013, 91, 869-881. [CrossRef] [PubMed]

8. Tiwari, S.; Singh, N.S.; Garg, S.K. Induced phytoremediation of metals from fly ash mediated by plant growth promoting rhizobacteria. J. Environ. Biol. 2013, 34, 717-727.

9. Zacchini, M.; Pietrini, F.; Mugnozza, G.S.; Iori, V.; Pietrosanti, L.; Massacci, A. Metal tolerance, accumulation and translocation in poplar and willow clones treated with cadmium in hydroponics. Water Air Soil Pollut. 2009, 197, 23-34. [CrossRef]

10. Tangahu, B.V.; Abdullah, S.R.S.; Basri, H.; Idris, M.; Anuar, N.; Mukhlisin, M. A review on heavy metals (As, $\mathrm{Pb}$, and $\mathrm{Hg}$ ) uptake by plants through phytoremediation. Int. J. Chem. Eng. 2011. [CrossRef]

11. Goswami, S.; Das, S. A Study on cadmium phytoremediation potential of Indian mustard, Brassica juncea. Int. J. Phytorem. 2015, 17, 583-588. [CrossRef]

12. Pandey, V.C. Invasive species based efficient green technology for phytoremediation of fly ash deposits. J. Geochem. Explor. 2012, 123, 13-18. [CrossRef]

13. Jamil, S.; Abhilasha, P.C.; Singha, N.; Sharma, P.N. Jatropha curcas: A potential crop for phytoremediation of coal fly ash. J. Hazard. Mater. 2009, 172, 269-275. [CrossRef] 
14. Pandey, V.C. Phytoremediation of heavy metals from fly ash pond by Azolla caroliniana. Ecotoxicol. Environ. Saf. 2012, 82, 8-12. [CrossRef] [PubMed]

15. Adesodun, J.K.; Atayese, M.O.; Agbaje, T.; Osadiaye, B.A.; Mafe, O.; Soretire, A.A. Phytoremediation potentials of sunflowers (Tithonia diversifolia and Helianthus annuus) for metals in soils contaminated with zinc and lead nitrates. Water Air Soil Pollut. 2010, 207, 195-201. [CrossRef]

16. Sakakibara, M.; Ohmori, Y.; Ha, N.T.H.; Sano, S.; Sera, K. Phytoremediation of heavy metal contaminated water and sediment by Eleocharis acicularis. Clean Soil Air Water 2011, 39, 735-741. [CrossRef]

17. Shabani, N.; Sayadi, M.H. Evaluation of heavy metals accumulation by two emergent macrophytes from the polluted soil: an experimental study. Environmentalist 2012, 32, 91-98. [CrossRef]

18. Lichtenthaler, H.K. Chlorophylls and carotenoids: Pigments of photosynthetic biomembranes. In Methods in Enzymology Plant Cell Membranes; Sies, H., Douce, R., Colowick, N., Kaplan, N., Eds.; Academic Press: San Diego, CA, USA, 1987; Volume 148, pp. 350-381.

19. Pandey, V.C.; Singh, K.; Singh, R.P.; Singh, B. Naturally growing Saccharum munja on the fly ash lagoons: A potential ecological engineer for the revegetation and stabilization. Ecol. Eng. 2012, 40, 95-99. [CrossRef]

20. Mattigod, S.; Rai, D.; Eary, L.; Ainsworth, C. Geochemical Factors controlling the mobilization of inorganic constituents from fossil fuel combustion residues: II. Review of the major elements. J. Environ. Qual. 1990, 19, 188-201. [CrossRef]

21. Gitari, W.M.; Petrik, L.F.; Key, D.L.; Okujeni, C. Partitioning of major and trace inorganic contaminants in fly ash acid mine drainage derived solid residues. Int. J. Environ. Sci. Technol. 2010, 7, 519-534. [CrossRef]

22. Sumanta, N.; Haque, C.I.; Nishika, J.; Suprakash, R. Spectrophotometric analysis of chlorophylls and carotenoids from commonly grown fern species by using various extracting solvents. Res. J. Chem. Sci. 2014, 4, 63-69. [CrossRef]

23. Strzalka, K.; Kostecka-Gugala, A.; Latowski, D. Carotenoids and environmental stress in plants: Significance of carotenoid-mediated modulation of membrane physical properties. Russ. J. Plant Physiol. 2003, 50, 168-173. [CrossRef]

24. Gitari, W.M.; Petrik, L.F.; Etchebers, O.; Key, D.L.; Okujeni, C. Treatment of acid mine drainage with fly ash: Removal of major contaminants and trace elements. J. Environ. Sci. Health A Tox. Hazard. Subst. Environ. Eng. 2006, 41, 1729-1747. [CrossRef]

25. Maiti, S.K.; Jaiswal, S. Bioaccumulation and translocation of metals in the natural vegetation growing on fly ash lagoons: A field study from Santaldih thermal power plant, West Bengal India. Environ. Monit. Assess. 2008, 136, 355-370. [CrossRef] [PubMed]

26. Pandey, V.C.; Singh, N. Impact of fly ash incorporation in soil systems. Agric. Ecosyst. Environ. 2010, 136, 16-27. [CrossRef]

27. Pandey, V.C.; Abhilash, P.C.; Singh, N. The Indian perspective of utilizing fly ash in phytoremediation, phytomanagement and biomass production. J. Environ. Manag. 2009, 90, 2943-2958. [CrossRef] [PubMed]

28. Sinha, S.; Gupta, A.K.; Bhatt, K. Uptake and translocation of metals in Fenugreek grown on soil amended with tannery sludge: Involvement of antioxidants. Ecotoxicol. Environ. Saf. 2007, 67, 267-277. [CrossRef] [PubMed]

(C) 2018 by the authors. Licensee MDPI, Basel, Switzerland. This article is an open access article distributed under the terms and conditions of the Creative Commons Attribution (CC BY) license (http://creativecommons.org/licenses/by/4.0/). 